This item was submitted to Loughborough's Research Repository by the author.

Items in Figshare are protected by copyright, with all rights reserved, unless otherwise indicated.

\title{
Research practice into/influencing mathematics teaching and learning development: towards a theoretical framework based on co-learning partnerships
}

\section{PLEASE CITE THE PUBLISHED VERSION}

http://www.springerlink.com/content/r157123653tr7477/

\section{PUBLISHER}

(C) Kluwer Academic Publishers

\section{VERSION}

AM (Accepted Manuscript)

\section{LICENCE}

CC BY-NC-ND 4.0

\section{REPOSITORY RECORD}

Jaworski, Barbara. 2019. "Research Practice Into/influencing Mathematics Teaching and Learning Development: Towards a Theoretical Framework Based on Co-learning Partnerships”. figshare. https://hdl.handle.net/2134/8805. 
This item was submitted to Loughborough's Institutional Repository (https://dspace.lboro.ac.uk/) by the author and is made available under the following Creative Commons Licence conditions.

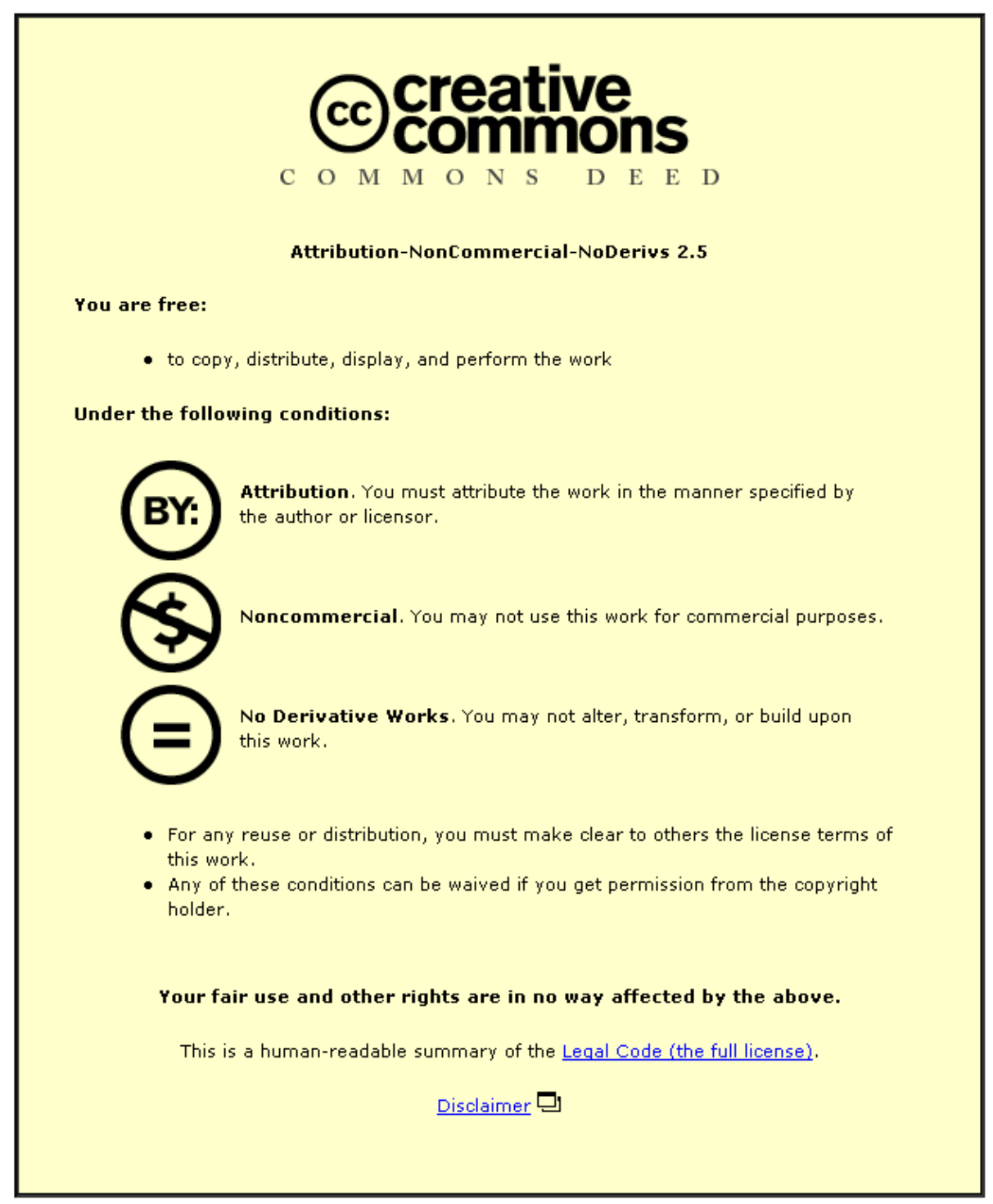

For the full text of this licence, please go to: http://creativecommons.org/licenses/by-nc-nd/2.5/ 


\title{
RESEARCH PRACTICE INTO/INFLUENCING MATHEMATICS TEACHING AND LEARNING DEVELOPMENT:
}

\section{TOWARDS A THEORETICAL FRAMEWORK BASED ON CO-LEARNING PARTNERSHIPS}

\author{
Barbara Jaworski - Agder University College, Norway
}

\begin{abstract}
This paper addresses issues linking research into the classroom teaching and learning of mathematics with the growth of knowledge in mathematics teaching, developments in the practice of teaching and the enhanced learning of mathematics by students in classrooms. A basic premise is that research promotes development. The paper considers both insider and outsider research and co-learning between teachers and educators in promoting classroom inquiry. Through a consideration of elements of theory such as knowledge and inquiry in teaching and of learning as knowledge growth through research/inquiry leading to enhancement of students' learning of mathematics, a framework is suggested. Its purposes include analysis of a research project's contribution to teaching development and conceptualization of research which has teaching development as one of its aims. Use of the framework is exemplified through its application to reports of three mathematics education research projects in the public domain. A brief afterword links the framework to concepts in activity theory.
\end{abstract}

Key words: research into learning and teaching mathematics; knowledge and development of mathematics teaching; co-learning between research participants; relationships between insider and outside research; classroom inquiry as a developmental tool.

Department of Mathematics

Service Box 422

$\mathrm{N}-4604$ Kristiansand

Norway barbara.jaworski@hia.no

Phone: +47 38141627

Fax: +47 38141071 


\section{Introduction}

\section{My purpose and task in this paper}

This paper is about the practice of research and the development of mathematics teaching and learning from a perspective of co-learning. I want to look at ways in which the development of mathematics teaching and learning is enhanced by research in mathematics classrooms, and to establish a theoretical framework to characterise such research and its developmental outcomes. It was hard to capture in a simple title the inter-related nature of the two major parts of the title. The words into and influencing try to capture this inter-relationship. It includes researchers exploring from the outside and/or teachers exploring from the inside (Bassey, 1995), and, ultimately, the value of these practices influencing each other for improved teaching. According to Bassey “The term 'insider' means a practitioner engaging in research on some aspect of his or her own practice, while an 'outsider' is a researcher from the outside” (p. 6). In the second part of the paper, I provide examples of these positions and how they are manifested in research and practice.

I am taking a perspective of co-learning as expressed succinctly by Jon Wagner (1997) in his three-fold framework for researcher-practitioner cooperation as follows: In a co-learning agreement, researchers and practitioners are both participants in processes of education and systems of schooling. Both are engaged in action and reflection. By working together, each might learn something about the world of the other. Of equal importance, however, each may learn something more about his or her own world and its connections to institutions and schooling. (Wagner, 1997, p 16)

Co-learning is one of three modes in which, Wagner suggests, researchers and practitioners interact: data extraction agreements, clinical partnerships and colearning agreements. In the first of these, outsider researchers conduct research in classrooms where pupils and teachers are subjects of research and minimally participant in that research. In the second, outsider researchers conceive and manage the research, but teachers are drawn into participation and their perspectives and engagement are central to the study. In the third, research is conceived and conducted jointly by outsiders and insiders; these 'partners' often have different although mutually sustaining roles and goals. 
Importantly for this paper and associated research, I extend Wagner's notion of co-learning to include insider researchers, those practitioners who also engage in research into teaching, and hence develop their own teaching. Although, predominantly, this means teacher-researchers, it can also include student-researchers, in which case it extends to mathematical action and reflection in the mathematics classroom. It can include educator-researchers exploring processes and practices in teacher education. In this paper, I am focusing mainly on teachers as participants and researchers in classroom research which may have originated with outsider researchers (people like myself, for example, who work as educators and conduct research with teachers). Technically, according to Wagner's typology, my focus on co-learning will include some relationships more accurately classified as clinical partnerships (examples are given in Jaworski, 2001b).

Analysis here parallels that using a model concerning 'sustained interactivity' between researchers and practitioners in which 'the goal of research [develops] from one of primarily informing the practitioner to one of jointly constructing knowledge through shared activity’ (Huberman, 1999,p. 291). Huberman’s group explored particularly the learning of outsider researchers: they applied their model to a case study of researchers engaged in the exchange of findings with schools - the Cognitively Guided Instruction project in Madison, Wisconsin - and to a set of ‘intellectual biographies’ of science and mathematics education researchers who followed 'distinct lines of inquiry while maintaining regular contacts with the field' (p. 294). Huberman emphasizes that 'micro-worlds' of research and practice interact and determine a flow of knowledge, and that it is interaction between microworlds, rather than the actors alone, that is their crucial unit of analysis. Nevertheless there was tentative evidence that sustained interactivity between practitioners and researchers may be beneficial to the latter as well as to the former. Evidence from my own research and that of others cited below (e,g, Jaworski, 2001a; Mohammad, 2002) shows overtly the enhanced knowledge and practice of educator researchers, although that is not my main focus in this paper.

Thus, in seeking a theoretical framework, this paper has two main focuses

I Research into mathematics learning, teaching and teaching development involving both insider and outsider research or inquiry; 
II The contribution of such research or inquiry to the development of teaching, and the related learning of mathematics, through co-learning relationships between participants at a variety of levels.

I am building here on a number of papers already published in which examples are provided of relationships between teachers and educators in co-learning situations premised on the development of mathematics teaching and the ultimate enhancement of mathematics learning in classrooms (Jaworski, 1998, 1999, 2001a,b; Potari \& Jaworski, 2002). In the present paper, I propose first a framework through which to analyse studies (and construct further studies) in this area, and then begin to seek validity for the proposed framework through its application, briefly, to three research studies reported in published literature.

\section{Framework objectives}

The framework will:

1. Look in two directions simultaneously:

a) at research into mathematics learning, teaching and/or teaching development from insider and outsider perspectives;

b) at mathematics teaching development occurring in parallel with such research;

and provide an approach to analysing relationships between the two;

2. Contribute to a conceptualisation of such relationships;

3. Contribute to developing mathematics teaching and learning.

I emphasise that the framework is still tentative and open to modification or enhancement, for example through connections to activity theory as indicated in my 'afterword'.

\section{Situating the task socially and societally}

As my intention is that the framework will be applied to situations of human interaction, involving students, teachers, educators and researchers, social and societal issues are important to its constitution. I will therefore take a moment to situate the task here more broadly with relation to other work that tackles such issues or problems. In the final chapter of a collection of papers called, Understanding practice: Perspectives on activity and context, one of the editors, Seth Chaiklin, writes as follows: 
Social science research has the potential to illuminate and clarify the practices we are studying as well as the possibility to be incorporated into the very practices being investigated. (Chaiklin, 1996, p. 394. Emphasis added.)

These words emphasise the nature of research, not only as a means to illuminate practice, but as a source of study in investigations of practice; the research itself being part of the practice under investigation. These notions, and indeed much of Chaiklin's chapter, support the premise we have here that research into teaching and teaching development contributes to developing mathematics teaching and hence learning. The aim of such theorising, ultimately, is to enhance mathematics teaching and learning and their development. It is a practical aim, socially and societally rooted: socially, because it is fundamentally about human development, the learning about mathematics, or about mathematics teaching, of human beings (students, teachers, educators ... ) individually and in groups; societally, because values in the human learning of mathematics derive from perspectives of education as conceived by societies in which learning takes place. Mathematics teaching itself is not usually a collective endeavour; it is achieved, usually, by individual teachers working with particular groups of students in particular settings. However, it becomes collective as norms and values permeate society and individual practices draw on and feed societal expectations. On the other hand development of teaching, while taking place within the practice of individuals, can be seen as a collective enterprise and indeed needs to be so for wide effect. We might argue that individual teachers' development of mathematics teaching is most effective when it takes place in a supportive community through which knowledge can develop and be evaluated critically (Jaworski, 1998, 1999, 2001a), and moreover in which new norms emerge to influence cultures of practice. This premise is the basis of the co-learning relationships proposed here.

Relating to studies reported in the chapters of the book on which he reflects, Chaiklin argues for the importance to a development of practice of "developing theoretical concepts from a theoretical tradition”. He continues

Studies in this area try to develop a theoretical account of actions (or possibilities for actions) of individuals participating in a societally significant practice, while it is occurring. (Chaiklin 1993, p. 386)

In seeking a theoretical framework, I am trying to capture the essences of mathematics teaching development from a perspective of co-learning and the 
enhancement of such practices through research that explores them. In accord with Chaiklin's words, I have tried to start from 'theoretical traditions' which can be seen as underpinning the practices I seek to explicate further. These traditions provide starting points for the proposed framework.

\section{Areas of theory underpinning the proposed framework}

This section will explore, necessarily briefly, some theoretical ideas, areas or traditions from which key elements of a proposed framework will emerge. These areas are:

- Knowledge in teaching;

- Communities of inquiry in teaching;

- Recognition of the role of research (or inquiry) in developing knowledge in teaching;

- Growth of knowledge in teaching related to academic programmes through which

co-learning develops

- Research in mathematics teaching and its relationship to the learning of mathematics.

- Intersubjectivity and community knowledge

My aim through this exploration is to offer a theoretical story or picture that helps to make sense of relationships between research and development in learning and teaching mathematics.

\section{Knowledge in teaching}

Teaching knowledge has been a focus of research in education broadly, particularly over the last decade, where scholars such as Shulman (e.g., 1987), Eraut (e.g., 1994) and Brown and McIntyre (1993) (amongst many others) have sought to explicate this knowledge and attend to its multilevel dimensions and issues for teachers and teaching broadly. For example, the question of what knowledge teachers have is addressed by Shulman's (1987) list of seven bases for professional knowledge in teaching: content knowledge (in our case, knowledge of mathematics); general pedagogical knowledge; curriculum knowledge; pedagogical content knowledge (e.g., pedagogy particularly related to mathematical learning); knowledge of learners; 
knowledge of educational contexts; knowledge of educational purposes and values (p. 8). In mathematics education, Even and Tirosh (2002) have elaborated on Shulman's term 'pedagogical content knowledge' to look particularly at forms of knowledge in mathematics teaching and their relation to knowledge in mathematics itself. There is considerable research into teachers' mathematical knowledge (content knowledge) and its relationships (or lack of them) with effective teaching (e.g. Grossman, Wilson and Shulman 1989; Askew, Brown, Rhodes, Johnson and Wiliam, 1997; Rowland, Martyn, Barber and Heal, 2000)

We could also ask what kinds of knowledge teachers have or need to have. Eraut (1994) offers the following categories: procedural knowledge, propositional knowledge; practical knowledge; tacit knowledge; skills and know-how (p.16). Eraut emphasises that how these forms of knowledge develop for any teacher is related to contexts of learning, which must influence teachers' interpretation, personalisation and incorporation into conceptual frameworks (ibid, e.g., pp. 19, 157). Considerable research in mathematics education has explored relationships between teachers' beliefs and their classroom actions (Thompson, 1992) and ways in which knowledge and beliefs are related (e.g., Cooney, Shealy and Arvold, 1998). Cooney and colleagues write, "We claim that knowledge constructed from a relativistic perspective in which one's voice is a partner in that construction is necessary in order for a teachers to become the reflective practitioner of which Schön $(1983,1987)$ speaks” (p.330). I build further on Schön’s theories below.

The status and validity of knowledge, particularly of practical knowledge, is seriously value-laden, so it is hard to define truth - what is right or wrong in classrooms, or indeed what we count as effective teaching. For example, Eraut asserts that teachers hold 'images and impressions' in their minds which are 'not represented in propositional form although propositions may be derived from them through reflection’ (Eraut, 1993, p. 227). Claxton (2000) elaborates the 'intuitive’ nature of teachers' knowledge, building on notions of tacit knowledge, to suggest that teachers develop strong intuitions on which teaching decisions are based. Cooney (1987) provided examples of mathematics teachers' decisions and their relation to 'critical moments' for the teacher in classroom practice. What emerges from considerations and analyses of teaching knowledge, its acquisition and use, is the personal nature and context-relatedness of knowledge, and its corresponding unpredictability of 
application in classroom situations (e.g., Eraut (1993), Wilson Shulman and Richert, 1987).

In contrast to studies that theorise aspects of teachers' knowledge, Brown and McIntyre (1993) studied how particular teachers explicate and use their knowledge in professional action in naturalistic settings of their own school and classroom. They observed teachers establishing 'normal desirable states of pupil activity' - a lesson 'was seen as satisfactory so long as pupils continued to act in those ways which were seen by the teacher as routinely desirable. Normal desirable states varied from one teacher to another. (p.54). Even and Tirosh (2002) provide examples from mathematics classrooms to exemplify and explicate teachers' knowledge in practice. Many studies in mathematics education recently offer deeply analysed cases of teachers' knowledge and thinking and its contribution to teaching development (e.g., Skott, 2001; Sherin, 2002). Such research takes us closer to the practice of teaching, in order to inspect theory. The growth of research in these areas demonstrates the importance of understanding teachers' knowledge, its nature and sources, to considerations of improving teaching practice.

\section{Communities of inquiry in teaching}

Teachers operate within communities which form and legitimise practice such as schools, classrooms and subject departments. Thus, while Brown and McIntyre's 'normal desirable states' can be interpreted as ways of being, understanding and developing teaching established by individual teachers in their own classrooms, they can also be seen as the norms and practices, of school-in-educational-systems, that operate within a societal community. Lave and Wenger's (1991) theories of community of practice, where knowledge is in the practice, can be interpreted in a school context in which one layer of learning is that of teachers developing knowledge of teaching. Teachers may be seen to grow into the practices of teaching through participating in the practice of teaching as part of the community of teachers within a school. One problem with this way of seeing the growth of teaching knowledge is that it seems that it would perpetuate existing practices, whether or not these are conducive to pupils’ learning.

More recently, Wenger (1998) has emphasised the production of identity through participation in a community of practice. Learning is presented as a "process of becoming”. Wenger states, "It is in that formation of identity that learning can 
become a source of meaningfulness and of personal and social energy” (p. 215). Such formation of identity might be seen to incorporate an element of critique or inquiry into the teaching process: as part of normal practice, most likely in collaboration with colleagues, to ask questions about teaching and its relationships with pupils' learning, and to derive ideas and theories that can be tested through classroom inquiry. Schoenfeld (1996) has described, vividly, a ‘community of inquiry’ that developed through his mathematics education research group in a university environment. Considerable work in the UK, over three decades, has explored inquiry or investigation in mathematics teaching, and ways in which teachers develop approaches to the uses of inquiry in mathematics classrooms (e.g., Ahmed, 1987; Love, 1988; Mathematical Association, 1991; Jaworski, 1994). Such approaches to inquiring into teaching are closely allied with inquiry into mathematics as a basis for mathematical learning in classrooms (e.g., Banwell, Sauders \& Tahta, 1972; Mason, Burton \& Stacey, 1984; Schoenfeld, 1985). A perceived shift from community of practice to community of inquiry provides a theoretical perspective through which reflective development of teaching by individual teachers results in a developing community (Wells, 1999).

A feature of a community of inquiry that distinguishes it from a community of practice, according to Wells, is

the importance attached to meta-knowing through reflecting on what is being or has been constructed and on the tools and practices involved in the process' (page 124).

He adds that 'the construction of understanding is a collaborative enterprise' (p. 125).

Thus, we come to a thesis of this paper, that co-learning between teachers and researchers through inquiry and reflection into mutually supportive practices contributes to the development these practices. The practices here include teaching, inquiry into teaching, and elements of teacher education.

\section{Recognition of the role of research (or inquiry) in developing knowledge in teaching}

In a community of inquiry relating to mathematics classrooms, participants at all levels are learners: this includes beginning teachers, practising teachers, in-service teachers and teacher educators. Such learning results from the thoughtful and active nature of an inquiry approach to practice. Clark and Peterson (1986), with reference to 
Shulman's work, talk about the teacher as 'a thoughtful professional' (Peterson, 1988). Cooney (1984) talks about teachers' 'implicit theories of teaching and learning' which influence their teaching decisions and classroom acts. Elbaz (1990) writes about the important of encouraging the expression of teachers' own 'voice' in order to 'redress an imbalance which had in the past given us knowledge of teaching from the outside only'. Smyth (1987) claims that it is only by exercising and intellectualizing their voice, through a critical approach to teaching, that teachers will be empowered in their own profession. These references chart a progression from recognising teachers as thoughtful professionals to acknowledging the importance of teachers' overt expression of their thinking in a critical form. Smyth writes,

Put simply, to act reflectively about teaching is to actively pursue the possibility that existing practices may effectively be challenged, and in the light of evidence about their efficacy, replaced by alternatives. Reflection, critical awareness or enlightenment on its own is insufficient - it must be accompanied by action. (Smyth, 1991, p. 44/5)

Smyth suggests that being critical involves more than a reflective approach to teaching, it requires action. Kemmis (1985) sees the reflective process itself as demanding action. He argues

We are inclined to think of reflection as something quiet and personal. My argument here is that reflection is action-oriented, social and political. Its product is praxis (informed, committed action) the most eloquent and socially significant form of human action. (p. 141).

Dewey (1933) wrote about reflection as involving action in response to a perceived problem: 'Demand for the solution of a perplexity is the steadying and guiding factor in the entire process of reflection' (p. 14).

From these notions, we can conceive of inquiry as a form of critical reflection in which ‘informed, committed action’ is a fundamental characteristic. Research shows the growth of inquiry approaches facilitating knowledge development at all levels and influencing communities within schools, educational localities and the educational establishment (e.g., Hamilton, 1998). In particular, collaborative inquiry bridging the school/university divide is enabling growth of both individuals and the wider educational community in mathematics education (e.g. Jaworski, 1998, 1999; Krainer, 1998, 2001). When such inquiry is conducted in a systematic manner and its results 
made public, it becomes research (Stenhouse, 1984). The kinds of research involved may vary from practitioner-research (insider research - research) designed to enhance practice, to more formal research designed to enhance knowledge in a generalised sense (outsider research - Research ${ }^{1}$ ).

In the UK for example, the teacher-researcher movement, dating back to Stenhouse (e.g., Elliott, 1991), has been reinterpreted through establishment funding, resulting from critical debate between government and academy. The award of Best Practice Research Scholarships (http://www.dfee.gov.uk/bprs/) by the government Department for Education and Skills (http://www.dfes.gov.uk) required that part of the funding was used for collaboration between teachers and higher education researchers. This designation of funding acknowledged the value of such collaboration to improving teaching practice and leading to enhanced learning experiences for pupils in classrooms ${ }^{2}$. Thus, research in classrooms, undertaken by teachers supported by educators, took on a legitimacy through which communities of researchers could develop across school/university boundaries.

\section{Growth of knowledge in teaching related to academic programmes through which co-learning develops}

The history of teachers engaging in research into their own teaching shows that this has occurred most frequently when teachers engage in courses, academic programmes or research projects in which teacher research is encouraged and supported, often through collaborative action research (e.g., Elliott, 1991). It is very hard for teachers alone to undertake research; research is a very different activity from teaching (McIntyre, 1997), even though some teachers see their practice of planning, teaching and reflecting on teaching as a research process (Jaworski,1998).

\section{a) Courses, programmes and research projects initiating, encouraging and supporting teachers as researchers;}

In different parts of the world academic programmes at a variety of levels have encouraged teachers to engage in research in an accredited process from which some product - degree, diploma or certificate - results. Vulliamy and Webb (1992) talk about the process-product distinction in such a programme, and show that an evaluation of their programme rated the process as, or more, important than the product (the degree, etc.). Although teachers may have registered for the programme with certification in mind, the professional learning that resulted from their research or inquiry became more significant for many of them. In mathematics education, 
many such programmes have reported the importance of the process of engagement in research or inquiry for professional learning and development (e.g., Krainer, 1993; Britt, Irwin, Ellis \& Ritchie, 1993). Thus, engagement in individual inquiry for each teacher, results in knowledge growth that enhances that individual's teaching. Many such programmes, including those just mentioned, highlight the contribution of collaboration between members of a programme including both teachers and the educators who run the programme. The Best Practice Research Scholarships offered a variation on this model as it was the teachers who gained the funding and invited collaboration from their educator colleagues.

\section{b) Relationships between teachers-and-teachers and teachers-and-educators.}

In theorising from the programme in which he has been involved for many years, Krainer (1998) points to the significance of elements of autonomy and networking. Teachers' growth of knowledge, both individually, in terms of their increased autonomy, and collaboratively, in terms of the development of networks between teachers and other researchers, is clearly demonstrated. Krainer emphasises the importance of the programme also for the development of knowledge by the originators of the programme, the teacher-educators.

Depending on the nature of the programme, the educators running and researching the programme may be seen as 'outsiders' while the teachers are 'insiders'. In looking for developments in teaching, it is the practices of the teachers on which research is focused. Insider research involves research by teachers into their own teaching. Individual research can take place, fruitfully, in a collaborative environment involving teachers either within a school or across a number of schools. The outsiders may fulfil a number of roles: they might help provide the environment, or community, of teachers and educators in which the research practices of the teachers can be shared and common ideas/issues addressed (e.g., Krainer, 2001); they might themselves be conducting research into classroom learning or teaching (e.g., Jaworski, 1994); they might be engaged in research into the collaborative programme through which teacher research is initiated and sustained, and teaching enhanced (e.g., Jaworski, 1998); they might be researching their own practices as educators in supporting teacher research (e.g., Jaworski, 2001a; Krainer, 2001), in which case they become insiders in researching their own practice. These roles are of course not mutually exclusive. 
Reports show that joint engagement in these academic or research programmes results in (co-)learning for all of their participants. It is clear that what is learned is neither the same for all, of the same form or at the same level. However, in colearning, the learning of one is dependent on the participation and learning of others: mathematics teachers and educators learn together with different roles, goals and learning outcomes, while engaged in common activity for mutual benefit (e.g. Jaworski, 2001a).

\section{Research in mathematics teaching and its relationship to the learning of mathematics}

How are our students of mathematics benefiting from our learning about teaching through research? For example, the BPRS awards were premised on creating better understandings of teaching for effective learning (http://www.dfee.gov.uk/bprs/); what is the evidence that teachers' engaging in research results in increased achievement (in mathematics) for their pupils? The rhetoric in teacher-research programmes, such as those mentioned above, suggests implicitly, if not explicitly, that these programmes lead to better teaching. What do we mean by better teaching?

One answer to this question is that the teaching is better informed, or more knowledgeable. This brings us back to considerations of knowledge with which this section began. Schön's writing about the development of professional knowledge through reflective practice is now well known $(1983,1987)$. As teachers engage in research or inquiry, ask questions about their practice and explore aspects of practice, their knowledge develops.

In Schön's theory, reflection and action are fundamentally linked in three stages of reflection-on-action, reflection-for-action and reflection-in-action. One interpretation of his use of these terms is that

reflection on and for action by a teacher looking critically at what has happened in practice and planning for future practice leads to

an enhanced awareness of issues and a theorising of concerns such that in moments of choice and decision-making in the classroom the teacher is able to make informed decisions in a moment of action. 
The better informed the decisions, the more likely they are to contribute to enhanced learning for students. Such a theory accords with Mason’s (2001) 'discipline of noticing', in which 'noticing-in-the-moment' leads to informed action in the moment in practice. Eraut questions whether teachers have the time in such classroom moments to reflect critically and act accordingly, and asks for more evidence of such practice (1994, 1995). From my own research I have conceptualised the possibility for reflection-in-action and provided examples from real classroom situations (Jaworski, 1994, 1998).

Discussion of critical reflection and of reflection-in-action re-emphasises views of Eraut and others that we need more evidence of reflective practices and inquiry approaches enhancing teaching knowledge and enabling action 'in the moment'. Such evidence can only come from real opportunities for teachers to engage in reflective practice. Research shows that real opportunities are unlikely to arise without support and encouragement for teachers’ critically reflective engagement (e.g., Vulliamy \& Webb, 1992; Atkinson, 1994; Jaworski, 1994). Support can be of many forms, but in a co-learning situation it derives from collaboration between teachers, educators and researchers in a variety of forms. With such support, further research is needed to show relationships between research or inquiry and pupils' mathematical learning.

\section{Intersubjectivity and community knowledge}

The above discussion about individual inquiry and reflective activity, and its relationship to collaboration and community support, raises epistemological questions. Through individual inquiry, often supported by a collaborative community, individual knowledge grows (Jaworski, 2001a; Krainer, 2001). The individual teacher/learner draws on knowledge in the community as well as on personal knowledge. The community learns, through collaborative activity, from the thinking, practices, and development of the individual. There seems to be a mutually reflexive process of knowledge growth between individuals and the community. This raises epistemological questions of the nature and status of knowledge in individual versus social domains, and indeed of societal knowledge (Lerman, 1996; Steffe \& Thompson, 2000; Kieran, Forman \& Sfard, 2001). Lerman's (2001) metaphor of the zoom of a lens encourages an eclectic position with respect to the growth of knowledge: where the focus is on individual teachers' learning, for example, a constructivist perspective can explain coming to know; zooming out to community or 
societal influences suggests the need for sociocultural perspectives. These remarks offer no more than a recognition that such issues need to be addressed to explain intersubjectivity in communities of inquiry, and the dialectical nature of the shifting of knowledge between individual and community.

\section{An emerging story providing starting points for a framework}

In summarizing (very briefly) the above discussion of theory, a story or picture emerges as follows. We start and end with knowledge in teaching, and a fundamental premise that teachers' developing knowledge, their learning about teaching, will enhance teaching so that students' learning of mathematics is also enhanced. We see here a reflexivity of knowledge and learning emphasising the relationship between the breadth and depth of knowledge in teaching, and the growth of this knowledge through forms of learning. Developing knowledge is seen to occur through processes of inquiry involving critical reflection within a community of inquiry. Inquiry and reflection are reflexively related: inquiry having the overt intention to seek knowledge through questioning activity, and reflection, as indicated by Dewey (1933) and Kemmis (1985) involving critical scrutiny of practices that leads to informed action.

The community provides supportive structures for individual inquiry, and acts to mediate knowledge through sharing of experiences and developing of norms so that knowledge grows within the community as well as for each individual. Thus we obtain mutual elements of individual and community relationship forming a basis for inquiry and reflection and promoting learning and knowledge growth.

Research might consist of small scale inquiry, by insider researchers, directed towards development of their own teaching, possibly with outsider support. It might involve more formal research into mathematics learning or teaching conducted by outsiders (who are nevertheless a part of the research and education community involving classrooms and schools) and including insiders as significant partners in the research. Thus insiders and outsiders and the relationships between them constitute key elements of the research community in which knowledge and learning are promoted and teaching develops.

Key terms or elements from the above sections offering a theoretical background are the reflexive pairs knowledge and learning, inquiry and reflection, insider and outsider. individual and community. I want to emphasise that these pairs, or dimensions, are not poles; that I am not proposing some multiple form of dualism. 
Chaiklin (1996) has emphasised, for example, with respect to the pair individual and community, that individual and societal aspects of research often cannot be separated. He makes the point that

Individual researchers can personally absolve themselves from not satisfying the societal expectation of contributing to the public good because we (and 'they') believe that something will emerge from the collective activity [of all such individuals taken together].

Here, where individual and collective are concerned, I see a position in which the individual is supported in individual research through community involvement, while the community is enhanced through the learning and experiences of the individual acting within the community and society in which the community is rooted. Knowledge grows for both individual and community, and these are reflexively related. Ultimately, the critical focus of the framework must shift to considerations of how these various dimensions lead to enhanced learning of mathematics by students, hence to the societal expectations of mathematics teaching and learning.

\section{A Proposal for a Framework}

My proposed starting point is to develop a framework that can be applied to research that aims to address mathematics teaching development either from insider or outsider perspectives. Fundamental to such research is that it will take place within a colearning community involving teachers and others working collaboratively to develop teaching. Some of these participants will be engaged directly in research or inquiry into the teaching that is to develop.

I propose to take the four dimensions of

- knowledge and learning,

- inquiry and reflection,

- insider and outsider,

- individual and community, as set up above, and to use them to question the nature of a programme or project. An aim is to analyse the processes and practices of the research project and ways in which it contributes, or has contributed, to development of teaching and the enhanced mathematical learning of students. Particularly where research has not been designed overtly to effect development of teaching (and learning), the framework can reveal the 
extent to which research relationships in and of themselves foster development. The framework could also be used to inform a project proposal, before it is operational. I emphasise that the elements of the framework are deeply related and interlinked, for example, in the growth of individual or community knowledge through inquiry, and the growth of knowledge through co-learning involving both individual and community. Below, I offer some of the questions that might be addressed to the project or the proposal.

\section{Knowledge and Learning}

What and whose knowledge and what forms of knowledge are evident in the practices or teaching studied? How are these forms of knowledge explicated within the study? Who are the people learning, and whose learning is studied? What learning aims are explicit in the project? How are developing knowledge and learning studied and evidenced? What outcomes are sought in terms of knowledge and learning? In what ways is the mathematical learning of students enhanced through the project?

\section{Inquiry and reflection}

Who is inquiring? What is the focus and nature of inquiry - for example, what enhancement of teaching and/or learning is sought? How does research relate to the inquiry that is leading to development? What forms does reflection take? What outcomes are sought?

\section{Insider and outsider}

Who is conducting research or inquiry and into whose practice? For what purposes? What is the nature of the relationships involved? How are different members related to the whole project?

\section{Individual and community}

Who are the individuals involved? In what community did inquiry take place? What is the nature of the community? Who are the co-learners, and what forms of learning take place? What is the relationship between those engaging in research or inquiry how do individuals, or individual and community inter-relate? What norms are in place or in development? How does the community relate to wider society? How is learning in the project afforded or constrained by systemic or sociocultural, economic and political factors? 


\section{Applying the framework to reported research}

The proposed framework might be used either to initiate research or to analyse existing research in order to understand better its characteristics of contribution to teaching development. Chaiklin (1996) writes:

... research that attempts to understand human practices with attention to the societal context in which this practice is carried out is likely to develop descriptions that could be directly useful in that practice. [p.394]

Here, I have applied the framework to three research projects which I have labeled A, B and C for reference. I selected them as being different in their aims, conceptualization and operation, while yet each contributing to the growth of knowledge in teaching, enhancement of teaching practices and, explicitly or implicitly, the enhanced mathematical learning of students ${ }^{3}$.

I first describe each of these studies very briefly. I then present analyses organized according to the elements of the framework. Analyses are necessarily brief, picking out what seem like key elements of the studies with illustrative examples in some cases.

\section{A The KMOFAP Project in the U.K. (Black, Harrison, Lee, Marshall \& Wiliam, 2002; Wiliam, Lee, Harrison and Black, 2003)}

This project involved a study of formative assessment practices (FAP) and their development by teachers to enhance students' learning of mathematics. Researchers from London University, King’s College, worked with one mathematics and one science teacher in each of six schools in each of two Local Education Authorities

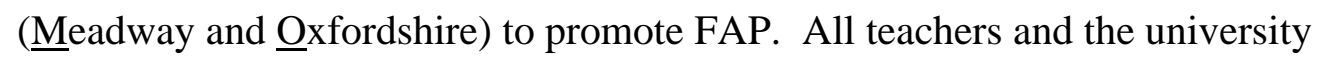
researchers met periodically at the university for seminars and sharing of practices and issues. University researchers visited teachers in schools to observe teaching and talk with teachers about issues and outcomes in their practice. A quantitative measure was devised to compare the enhancement of learning of selected pupils with that of a roughly comparable group in the school. This measure showed modest pupil gains over the life of the project, although certain issues in the use of such a measure had to be recognized. Considerable evidence was found of teacher learning and changed practices which went beyond particular classrooms to school and parent attitudes to assessment and learning. 


\section{B The VT Follow-up Project in Pakistan (Mohammad, 2002)}

Mohammad (2002) reports a doctoral study of the teaching practices of five secondary teachers who had returned to teaching in their schools after attending an 8-week Visiting Teacher (VT) course at a university in Pakistan. The VT course was tailored specially for experienced mathematics teachers to enhance their knowledge and practice in mathematics teaching. An expectation of the programme was that teachers, on returning to school, would implement what they had learned from the course. The researcher observed classroom lessons and held informal interviews with the teachers.

Analysis revealed that most teachers were teaching in much the same way that they and their colleagues had always taught, and that the course seemed to have had little impact on teaching. Teachers indicated that they had been given little help by professionals from the university or their school to make changes to their practice. They called on the researcher, as a teacher educator, to help them put into practice elements of their university learning. Thus the researcher moved into a second phase of research in which she worked with three teachers, as a teacher educator, and studied simultaneously the teachers' activity and developing practice, and her own role in working with the teachers. Outcomes sought were insights into teachers' learning, recognition of issues in teacher and teaching development, and feedback to the VT course.

\section{The Teaching and Learning Statistics Project in the U.S.A. (Heaton and Mickelson, 2002)}

Heaton and Mickelson (2002) described a project within a teacher education programme for novice elementary teachers in which students (the novice teachers) developed statistical knowledge and experience. The project introduced students to statistics through their own engagement with a statistical investigation, and, subsequently, their use of a statistical investigation as part of a curriculum topic with children in an elementary school. The researchers, Heaton and Mickelson, were a mathematics educator and a statistician respectively. They taught the students, and supervised, together with cooperating teachers in the students' 'practicum' schools, the students' teaching of the children.

The students wrote assignments reflecting on their experiences and learning in conducting their investigation. The study documents mainly the learning of students, 
but also that of children and educators as all engaged with statistical ideas related to investigations. The study found that integrating statistics into the elementary curriculum was 'a more difficult and complex teaching and learning problem than was expected'.

\section{Applying the framework to the three examples}

This section is organized on the framework dimensions, looking at each of the studies A, B and C in turn. I have used the framework questions articulated above to draw out key elements of each research study. As an appendix, I attach an outline of these key elements in tabular form.

\section{Knowledge and Learning,}

A: Teachers' knowledge of teaching and assessment practices such as questioning, feedback through marking, peer- and self-assessment and formative use of summative tests were evident from the study. There is evidence of growth of knowledge of such practices during the project: from awareness that such practices exist, are possible and have potential to promote more effective learning towards knowledge of their implementation and issues associated with their (effective) use. Knowledge was explicated through teacher reflection, discussion at university seminars, observations and interviews of outsider researchers with teachers. Teachers asked researchers for information about learning theories related to the practices they were developing in their classrooms.

Teachers used formative assessment strategies to evaluate pupils’ work, and to enable pupils to evaluate their own work. For example, the simple tool of 'traffic lights' was used by pupils to rate their own level of understanding of a topic - green being good and red poor understanding. Teachers' learning of formative assessment approaches, their classroom implementation and teachers' understanding of their contribution to students' learning were studied by the outsider researchers. There is considerable evidence that teaching practices became more 'knowledgeable' in so far as teachers were engaging overtly in designated practices and seeking to implement, evaluate and enhance those practices.

The project was explicitly focused on students' learning and its enhancement through formative assessment practices, and there is evidence that learning was indeed enhanced in qualitative ways, supported by a specially designed quantitative measure. 
B: The teachers' knowledge of mathematics and of teaching mathematics were forms of knowledge explicit in the project. The project revealed areas of mathematics with which teachers were insecure, and very limited perspectives of teaching activity, despite what had been addressed in the VT course.

The learning of the teacher educator was also a principle focus of the project: for example how to recognise areas of teachers' and teaching knowledge and associated needs; how to work with teachers to attend to these needs in sensitive ways with fruitful outcomes for classroom practice and students' learning of mathematics. Knowledge was explicated through qualitative analysis of observations of teaching, conversations with teachers and researcher's reflective writing. Issues in teaching and its development from the collaborative work between researcher and teacher comprised the main findings of the study.

It is not clear that students' understandings of mathematics were enhanced at all through the project. In some cases, remediating action had to be taken by the educator to prevent (further) damage to students' mathematical understanding through the changed practices of the teachers. This is exemplified in the quotation from the author regarding her intervention in the classroom, below.

C: Knowledge of statistics and of statistical investigations was fundamental to this project. The latter included also pedagogical knowledge related to statistics, and to mathematics more generally. For the educators it was important that students learned at all these levels. For the students, it was important that children learned statistics. Data and analysis focused on the students' learning in two phases, firstly their learning of statistics through undertaking their own statistical investigation; secondly their learning of teaching statistics through their use of a statistical investigation with children

Students' learning was studied through classroom observation, interviews with students and their cooperating teachers, and through students' project reports and written reflections. Educators learned about the difficulties and complexities of teaching and learning statistics using statistical investigations, and also about the pedagogy of educating students to teach statistics at elementary level.

The project had implications for children's learning in classrooms, not only about statistics but about social issues to which statistical study relates (as illustrated in the example quoted regarding 'discrimination'). It is hard to get a sense of the full 
nature and extent of the projects' contribution to children's learning from the one report consulted.

\section{Inquiry and reflection,}

A: Both teachers and outsider researchers were inquiring: teachers into their use of formative assessment processes and strategies; researchers into teachers' development of formative assessment, and the improvements in students learning outcomes.

Teachers are reported as engaging in reflection and many of the quotations provide evidence of this reflection and its relation to inquiry in their teaching; for example,

Increasing waiting time after asking questions proved to be difficult to start with - due to my habitual desire to 'add' something almost immediately after asking the original question. The pause after asking the question was sometimes 'painful'. It felt unnatural to have such a seemingly 'dead' period, but I persevered. Given more thinking time, students seemed to realize that a more thoughtful answer was required. Now, after many months of changing my style of questioning I have noticed that most students will give an answer and an explanation (where necessary) without additional prompting.

(Derek. Black et al, 2002, p. 5)

It seems that teachers' reflection was closely related to the formative assessment inquiry in which the project was engaging as such quotations make evident.

B: Primarily, the researcher was inquiring both into the teachers' learning and into her own learning as an educator. To a lesser extent, teachers were inquiring into their own knowledge and learning. Teachers were encouraged to reflect by the educator, and some wrote a reflective journal. For example, one teacher recognised a tension in encouraging students to give non-standard answers to classroom questions when a lesson was being observed by a school inspector:

If the students do not give an answer then the school [inspector] thinks that they have not learned anything. If they give unexpected answers then the impression is that the teacher had taught the same concept before. The blame is always on a teacher. (Sahib. Mohammad, 2002, p. 261) 
Teachers' reflection, through the activity of the educator, resulted in teachers changing their thinking and practice. Such changes revealed issues for teachers' learning relating to their school and personal expertise.

Educator reflections led to a critical examination of teachers' learning and the role of an educator in promoting teachers' learning; for example in a lesson on 'powers of 2' in which the teacher had declared that he wanted students to abstract a rule for exponents more generally, the educator perceived that the teachers' mathematical knowledge was insufficient to enable the students to understand the questions they were given. She writes:

I could have discussed that issue with the teacher in the feedback session as I believe that dialogue promotes shared understanding. However, the question was how would these students benefit from our discussion? The final examination was imminent. The teacher might not have time to clarify the students' concepts. There were possible consequences of students' failing the examination. I decided to support the students' as well as the teachers' learning through taking charge of the lesson. I did not want to humiliate the teacher from my interference in his teaching; therefore I phrased my intervention in this way; I asked him if I could continue his teaching as I developed interest in this topic. (Mohammed, 2002, p. 281-2)

Subsequent educator reflection questions the wisdom and ethics of such intervention with respect to the teacher's learning.

C: Inquiry took place in this project in a number of forms. One of these was statistical inquiry, or investigation. Elements of inquiry were evident in students' and children's involvement with statistical investigations. Inquiry into the learning and teaching of statistics using statistical investigations was done by the university researchers. The novice teachers did not engage overtly in inquiry into learning and teaching. However, it might be seen that they engaged implicitly in such inquiry as part of their analysis of their teaching of the children. Certainly students were required overtly to reflect on their own learning and that of the children in the project as part of their writing for assessment in their teacher education course. The authors report that this reflection was, for many students, a descriptive account of what they did and observed, lacking critical analysis. The educators reflected on ways in which student reflection contributed to students' learning of teaching statistics, and hence to 
their awareness and development of teaching, albeit at novice level. For example, the results of a survey into ‘discrimination' in a predominantly white, middle class school, conducted by sixth grade children led by the student teachers, did not turn out "exactly the way the sixth grade children at our practicum site expected" (p. 50). The authors indicate that this resulted in the children's animated engagement with issues unprompted by the student teachers leading the investigation. The authors quote their field notes as saying “... they [the children] are having a graduate level discussion of construct validity and external validity, it's in the language of sixth graders, but I wish some of my graduate students would have this type of discussion” (p. 50-51). They quote Connie, who, with her partner, had created the environment in which the children inquired into discrimination within their school. Connie wrote in her final dissertation:

I believe that they [children] learned more about discrimination from this than they would from reading articles on discrimination or from just reading the book on their own. It really invests a teacher and the children in the topic and because of that, the learning is more authentic and natural than otherwise. (Connie. Heaton and Mickelson, 2002, p.51)

The authors indicate that their own reflections as educators on outcomes from the project led to changes in their own teaching in a subsequent phase of the project.

\section{Insider and outsider,}

A: It seems clear that the outsider researchers were conducting the research into the teaching practices and the learning of pupils resulting from these practices. Insiders were the teachers in the project. The outsiders write,

... we decided that we had to work in a genuinely collaborative way with a small group of teachers, suggesting directions that might be fruitful to explore, and supporting them as well as we could, but avoiding the trap of dispensing 'tips for teachers'. At first, it seemed likely that the teachers did not believe this. They seemed to believe that the researchers were operating with a perverted model of discovery learning in which the researchers knew full well what they wanted the teachers to do, but didn't tell them, because they wanted the teachers 'to discover it for themselves'. However, after a while, it became clear that there was no prescribed model of effective classroom action, and 
each teacher would need to find their own way of implementing these general principles in their own classrooms. (Wiliam et al, 2003 - in press)

Teachers' overt exploration of alternative assessment approaches took the shape of a form of inquiry as witnessed in the quotation from Derek above.

Current writing suggests that negotiations took place between outsider researchers and the teachers, and that the project evolved through the development of relationships. For example, teachers agreed to come to meetings, but the timing and nature of meetings had to fit with what was possible in teachers' location and schedules. Teachers themselves indicated that they were interested in learning theory, so seminars addressed this. Teachers' involvement in exploring FAP in their classrooms led to teacher emancipation within the project, directing and managing their own involvement, albeit in contact and consultation with outsider researchers.

B: The researcher was inquiring into the learning of teachers (as an outsider) and into her own learning as an educator (as an insider). These roles were sometimes hard to separate as the latter influenced the former, and to some extent vice versa. Teachers' insider research into their own teaching was closely influenced by the activity of the educator in encouraging teachers' thinking, reflection and critical questioning. The author writes about this as follows: “I am reminded of Naeem's comment presented below, that shows his engagement in his development as a result of my intervention”.

... I know my responsibilities ... . Only thinking alone is a tiring job. I am not in the position to cope with all the mathematical and practical problems of mathematics teaching in the school. Your presence is my assistance, which is reducing my tension. (Naeem. Mohammed, 2002, p. 276)

A major issue became that of 'what happens when the (outsider) researcher goes away'? Realistic expectations were that teachers would find it difficult to continue reflective development without her presence and support.

C: The university researchers were both outsider and insider researchers in this project, although the first was explicit and the second more implicit. They researched as outsiders the learning and development of their students as novice teachers. They inquired as insiders into their own learning and development as educators.

Student teachers can be regarded as insider researchers to the extent that they inquired into their own learning and development. The quotation from Connie above 
is evidence of this of a sort. The requirement of the university course that the students wrote an assignment relating to their learning from their inquiry work with children required that the students' analysed their own role in the project and its contribution to children's learning. Although it was clear from what was written that the students learned from their experiences with inquiry, the authors felt that they had not really engaged with how inquiry per se had contributed to their developing practice.

\section{Individual and community,}

A: There was evidence of learning on the part of individual outsider researchers and individual teachers. No doubt growth of knowledge can be explored for each of these individuals (and has been documented to some extent already). Such growth can be related, certainly where teachers are concerned, both to individual activity and thinking, and also to several communities: e.g. the school community, the community of the project. Each teacher has a mini community with the visiting outsider researcher, and possibly with other project teachers in the school. Outsider researchers have their project community, plus the community of researchers in (mathematics) education more broadly. Learning relationships are complex as teachers learn with respect both to their projects and school/societal communities; outsider researchers learn with respect to the wider community of the project, but also in their association with the school communities with which they inter-relate.

There is evidence of school and institutionalised educational structures affecting the way the project was set up and implemented (Wiliam et al., 2003-in press); for example, the schools selected teachers who would be involved - in some schools, 'teachers appeared to be selected because, in the words of one head, "they could do with a bit of inset" ' ; some teachers, selecting focuses for classroom inquiry, chose to focus on issues relating to the implementation of the national curriculum or national assessment. Current writing suggests FAP becoming acceptable to school and parents, so that perceptions of the nature of assessment and its contribution to learning in society beyond the locality of classrooms becomes evident, making possible real changes in the delivery of the national curriculum.

B: Individual teachers each worked with the educator within the school community, but separate from it. Research provided evidence of conflict between individual development and collaboration with the educator. The teachers' role within the school community was evident and revealed serious issues for teachers and 
educators seeking to change practices within existing school cultures. It seemed that teachers were not only tackling issues in teaching per se, which was problematic in itself, but were doing so in opposition to community values and expectations which made the tackling of teaching issues an impossible task for them as individuals. For example, one teacher highlighted tensions for him in trying to foster conceptual learning relative to expectations within his school and society:

I have to complete the syllabus before the final examination. ... We check their memory and skills of drawing [geometrical shapes] in examination; conceptual clarification is not a basic requirement of the examination. If we 'check' [assess] their concepts, none of them will pass the examination. (Sahib. Mohammed, 2002, p. 263)

In relation to such issues, the educator was seen to struggle with personal ethics, theoretical knowledge based on research findings in the mathematics education community, and the cultures of Pakistani society and schooling. Like the teachers, she found herself alone in some of these struggles. However, the VT programme and associated activity with teachers was designed to affect students' learning in the longer term. It is inappropriate to judge this project in term of its impact on students' learning in the short term. The project revealed serious issues for such development programmes within the culture of Pakistan schools, and the society in which they operate.

C: Individual learners were children, students and educators. Educators were responsible for the individual learning and development of students, who were in turn responsible for the individual learning and development of children (alongside their cooperating teachers).

Students operated in the community of teacher education within the university involving their fellow students and educators, and in the community of their practicum school with children, teachers, fellow students, and visits from educators. That each of these communities contributed to their awareness, experience and insight is implicit in the report, but the authors' comments on the needs of future programmes indicates that the communities as currently constituted did not readily support the teaching of statistics through statistical investigations as was the aim of their programme. 
The project contributed to redesign of the course for further cohorts of student teachers, and so can be seen to have implications for teacher training more extensively which can only be hypothetical at the current stage.

\section{What is revealed by these analyses?}

Although research projects A, B and C are very different from each other, there is evidence of knowledge growth for teachers and educators that relates to interactions between outsiders and insiders and builds on reflective inquiry at a variety of levels. In all cases, individual learning is most evident although it can be seen to relate to community involvement, often implicitly and not always positively. It is harder to locate evidence of community development although, in A and C, there are indications that the project influenced curriculum delivery and course design respectively. In all cases, co-learning between insiders and outsiders is evident with clear delineation of alternative roles and goals.

Forms of knowledge that were highlighted in the reports included mathematical (and statistical) knowledge [B and C]; knowledge of pedagogic processes, often associated directly with the mathematics that was the focus of the teaching, e.g., statistical investigations and classroom approaches to conducting them; [C]. knowledge of assessment practices and their contribution to learning [A]. Evidence was presented of the development of all these forms of knowledge through the projects in which inquiry was a fundamental activity.

All participants in all three projects engaged in inquiry and reflection. For example, in [A] teachers were inquirers into FAP in their classrooms; in [C] student teachers were inquirers into the practices of conducting statistical investigations with children; in [B] the educator/researcher inquired into her own practices in enabling teachers to develop their knowledge, thinking and practices. Teachers in [B] were nurtured to engage in reflective inquiry, and developed confidence to do so while working with the educator; serious questions were raised as to the implications of their ongoing development when the project had to end.

Such relationships between teachers and educator-researchers seem to have influenced development in at least two of the projects [A and B]. In [A], teachers learned that their inquiry was genuine and not a doubtful game on the part of the researchers. This realization led to increased confidence in their own development of FAP. In B, teachers were encouraged by the educator-researcher to believe in their 
own possibility to change practices, albeit with the educator's support. Different forms and levels of community fostered such relationships. Others, such as the school community in which the teachers of [B] operated was perceived by the teachers as seriously in opposition to their developing practice. Thus, it was conjectured that when the educator left them, these teachers would resume the styles and approaches to teaching that prevailed within their school environment.

Notions of insider and outsider were highly complex across these projects. While in [A] outsiders were the university researcher and insiders the teachers in the schools, in [B] the educator/researcher was an insider exploring her own practices as an educator, along with teachers who were also insiders in reflecting on their own knowledge and teaching, studied by the educator/researcher as an outsider; in [C] student teachers were insiders, while their tutors were both outsiders, in researching the learning of the student teachers, and, implicitly, insiders in reflecting on their own practice as educators. Co-learning was evident at all levels of interaction in any project with the learning of any individual influenced and sustained by the activity and thinking of others. This activity is described variously as reflection, inquiry and research depending on the explicit and systematic nature in which questions were asked and explored, and outcomes analysed, evaluated and published.

Within this complexity, to look at teaching development for any individual would involve drawing on the complexity of inter-relationships and linking these to knowledge and its growth. For example, in [C], engagement of one student teacher (Connie) with statistical investigations, with her partner in a $6^{\text {th }}$ grade classroom, set up by her tutors through university seminars, evaluated by one tutor observing in the classroom and reported in her own reflective writing, contributed to her growth of knowledge and awareness of teaching. Such growth would have been evaluated formally within the teacher education programme. However, it is unlikely that this evaluation would have paid attention to the wide set of influences contributing to this learning. The framework, by drawing attention to such elements of development allows a critical appraisal of such developmental influences and the contribution of the (research) project to development.

In addressing these projects through their published reports, I had to recognize many incomplete answers to the framework questions. The authors of these reports were not writing them for analysis of this kind. Ideally, I would have interviewed the authors to get clearer answers to questions such as: 
* Teachers' knowledge of learning theory: how was this seen/evidenced in practice? Was such explication of knowledge formative for teacher/teaching development? [A]

* Was evaluation of children's learning a part of the student teachers' projects? In what ways was children's knowledge seen to develop through their engagement in statistical investigations? [C]

Discussion with the members of a project, rather than just a reading of a project report, can lead to deeper and perhaps alternative insights into learning and the relationships contributing to learning in the project. This activity leads to important research insights for all researchers in the discussion. The framework questions, therefore, have a formative effect for research understanding and development.

Ultimately, we come back to social and societal understandings and sociosystemic development. Project [A] has distinct possibilities to influence assessment at national levels. In doing so, it will need to analyse carefully ways in which the project as a whole has contributed to knowledge of FAP and to associated teacher and teaching development. Project [B] offers salutary, but unsurprising messages to the university-school partnership in which it was conducted. Such findings are already leading to a re-addressing of processes and practices in this partnership. Study [C] is influential in a rather more localized way in the design of programmes in the university. However, its reporting could lead to other institutions embarking on statistical investigations as a mode of student teacher development. In all cases, sharing of such research and awareness of its developmental contribution can lead to a greater awareness of connections between research and development, and to future models of developing teaching for students' enhanced learning of mathematics.

\section{In Conclusion}

This paper has suggested a framework, currently tentative, that might be applied to analyse research projects involving multilayered research into teaching and teaching development in order to understand better the processes and practices involved, and the impact and outcomes of the research. It has presented mainly the theoretical background to the framework. The three examples that are included are there just to illustrate the application of the framework to a project, and not to exemplify thoroughly what would be involved and what could be learned. In a real application, 
much more of the detail of the projects would be available: the framework would be used to help tease out the finer details of knowledge and its growth, relationships fostering growth, and social and societal outcomes (see note 3).

An important potential of the framework is to examine research proposals in order to be clearer in advance how research in the project will be organised, different layers related to each other, and ways in which the project will be evaluated in terms of its desired outcomes where development is concerned.

\section{Afterword}

I was grateful for the very detailed reviews this paper received through the ESM review process. All of them offered a most helpful critique. It seems important to mention the suggestion of one reviewer that discussion of knowledge and learning relating to social and societal significance might be recast in terms of an activity theory perspective. Subsequent work on these ideas led to my development of a mapping between the framework here and Engeström’s “mediational triangle” (Cole and Engeström, 1993; Engeström, 1998).

Insert figure 1 here

Figure 1: The mediational structure of an activity system (from Engeström, 1998)

The 'subject' might be teacher, educator, teacher-researcher or educator-researcher: the 'object' will vary according to subject. For example, an object for a teacher in FAP above might be the development of formative assessment activities with her pupils. In this case 'community' could be other teachers in the school, other teachers in the FAP project, or indeed all members of the FAP project; 'mediating artifacts' would include formative assessment tasks and instruments such as 'traffic lights'; 'division of labour' could be a self-contained classroom, or might involve collaborative agreements between teachers; the 'rules' would include school schedules, curricular and testing requirements and so on. For an educator-researcher from the external research team as subject, an object might be the enhanced teaching of the teacher using FAP artifacts, the enhanced mathematical learning of pupils of this teacher, and a greater personal understanding of the educative process whereby such development occurs through classroom research. Such a complicated set of objectives seems to go beyond one simple planar triangle. Interconnected activity systems (see Engeström 1998, p. 80) could highlight the inter-relationship between 
teacher(s) and educator(s) as insiders and outsiders involved in research together in classrooms.

Important for the framework offered above are considerations of individual and interrelated activity in terms of knowledge, learning, inquiry and reflection among insiders and outsiders, individual and community. Cole and Engeström (1993) discuss the distribution of cognition within a cultural-historical frame, and it would be both possible and potentially exciting to recast the framework in their terms of their timerelated model (see page 20). I plan to work further on these ideas and welcome communication with others who are interested.

\section{Notes}

1 Elsewhere, I have used $r$ and $R$ to represent aspects of informal or more formal research respectively (e.g., Jaworski, 2000).

${ }^{2}$ Teachers were invited to apply for Best Practice Research Scholarships in partnership with a higher education institution for support and resource to which a proportion of the funds in the scholarship would be paid. Collaboration between teachers and educators was intended to support teachers in developing their practice of teaching. Ironically, this initiative operated alongside the development of a National Numeracy Strategy draconian in its imposition of curriculum and approaches to teaching. At the time of completing this paper, BPRS are in their final year, funding for this initiative having been terminated.

${ }^{3}$ An earlier version of this paper was presented at two conferences, feedback from which contributed to further development of the framework. In the earlier version, the framework was applied to one of my own research projects (Jaworski, 1998). A copy of this version can be obtained by contacting me directly. 


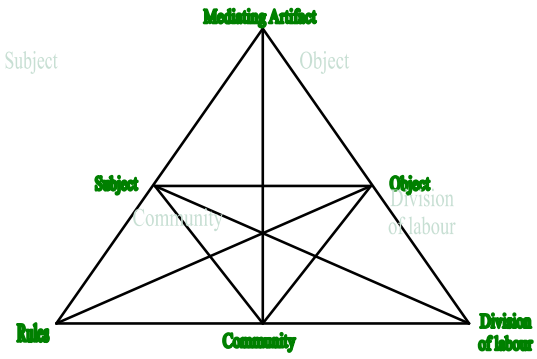

Figure 1 to be inserted in the text. 


\section{References}

Ahmed, A. (1987). Better Mathematics: A Curriculum Development Study. London: Her Majesty's Stationery Office.

Askew, M., Brown, M., Rhodes, V., Johnson, D. and Wiliam, D. (1997). Effective Teachers of Numeracy. London: King's College, Department of Education and Professional Studies.

Atkinson, S. (1994). 'Rethinking the Principles and Practice of Action Research: the tensions for the teacher-researcher.' Educational Action Research, 2(3), pp. 383-402.

Banwell, C. S., Saunders, K. D. and Tahta, D. S. (1972). Starting Points. Oxford: Oxford University Press.

Bassey, M. (1995). Creating Education Through Research. Edinburgh: British Educational Research Association.

Black, P., Harrison, C., Lee, C., Marshall, B and Wiliam, D. (2002) Working inside the black box: Assessment for learning in the classroom. London: Kings College, Department of Education and Professional Studies.

Britt, M.S., Irwin, K.C., Ellis,J., \& Ritchie, G. (1993). Teachers raising achievement in mathematics: Final report to the Ministry of Education. Auckland NZ: Centre for Mathematics Education, Auckland College of Education.

Brown, S. and McIntyre (1993). Making Sense of Teaching. Buckingham, UK: Open University Press.

Chaiklin, S. (1996).Understanding the Social Scientific Practice of Understanding Practice. In Chaiklin, S. \& Lave, J. (Eds.) Understanding Practice: Perspectives on Activity and Context. Cambridge: Cambridge University Press.

Clark, C. M. and Peterson, P. L. (1986). Teachers’ Thought Processes. In M. Wittrock (Ed.) Handbook of Research on Teaching. New York: Macmillan pp 255-296.

Claxton, G. (2000). The Anatomy of Intuition. In T. Atkinson and G. Claxton (Eds.) The Intuitive Practitioner: on the value of not always knowing what one is doing. Buckingham: Open University Press.

Cole, M. \& Engeström, Y. (1993). A cultural-historical approach to distributed cognition. In G. Salomon, (ed.) Distributed Cognitions: Psychological and educational considerations. Cambridge: Cambridge University Press.

Cooney, T. J. (1984). The Contribution of Theory to Mathematics Teacher Education. In H. G. Steiner et al (Eds.) Theory of Mathematics Education (TME), Bielefeld, Germany: Universitat Bielefeld/IDM.

Cooney, T. J. (1987). Teachers’ Decision Making. In D. Pimm (Ed.) Mathematics, Teachers and Children. London: Hodder and Stoughton. 
Cooney, T., Shealy, B., \& Arvold, B. (1998). Conceptualizing Belief Structures of preservice secondary mathematics teachers. Journal for Research in Mathematics Education, 29, 306-333.

Dewey, J. (1933). How We Think. London: D. C. Heath \& Co.

Elbaz, F. (1990). Knowledge and Discourse: The Evolution of Research on Teacher Thinking. In C. Day, M. Pope and P. Denicolo (Eds.) Insights into Teachers' Thinking and Practice. London: Falmer Press.

Elliott, J. (1991). Action research for educational change. Milton Keynes: Open University Press

Engeström, Y. (1998). Reorganising the motivational sphere of classroom culture: An activity-theoretical analysis of planning in a teacher team. In F. Seeger, J. Voigt \& U. Waschesio (Eds.), The Culture of the Mathematics Classroom. Cambridge: Cambridge University Press.

Eraut, M. (1993). The Characterisation and Development of Professional Expertise in School Management and in Teaching. In Educational Management and Administration, Vol 21 no. 4 pp. 223-232

Eraut, M. (1994). Developing Professional Knowledge and Competence. London: Falmer Press..

Eraut, M. (1995). Schön shock: A case for reframing reflection-in-action? Teachers and Teaching: Theory and Practice, 1 (1 ), 9-22.

Even, R. and Tirosh, D. (2002) Teacher knowledge and understanding of students' mathematical learning. In L. English (Ed.) Handbook of International Research in Mathematics Education. 219-240. Mahwah, NJ: Lawrence Erlbaum.

Grossman, P., Wilson, S. and Shulman, L. (1989). 'Teachers of substance: subject matter knowledge for teaching.' In M. Reynolds (Ed.), Knowledge Base for the Beginning Teacher (pp. 23-36). Oxford: Pergamon.

Hamilton, M. L. (1998). Reconceptualizing Teaching Practice: Self-Study in Teacher Education. London: The Falmer Press.

Heaton, R. M. and Mickelson, W. T. (2002). The Learning and Teaching of Statistical Investigation in Teaching and Teacher Education. Journal of Mathematics Teacher Education, 5, 1, 35-59.

Huberman, M. (1999) The Mind is Its Own Place: The Influence of Sustained Interactivity with Practitioners on Educational Researchers. Harvard Educational Review, Vol. 69, No. 3, pp. 289-319.

Jaworski, B. (1994). Investigating mathematics teaching: A constructivist inquiry. London: Falmer Press.

Jaworski, B. (1998). Mathematics Teacher Research: Process, Practice and the Development of Teaching. Journal of Mathematics Teacher Education, 1 pp 3-31. 
Jaworski, B. (1999). The Plurality of Knowledge Growth in Mathematics Teaching. In B. Jaworski, T. Wood and S. Dawson (Eds.) Mathematics Teacher Education: Critical International Perspectives. Dordrecht: Kluwer.

Jaworski, B. (2000). research or Research and its relation to Mathematics Teaching. In Proceedings of the Conference of the British Society for Research into Learning Mathematics, Vol 20 no 2 pp 98-103.

Jaworski, B. (2001a). Developing Mathematics Teaching: Teachers, TeacherEducators and Researchers as Co-Learners. In F-L Lin and T. J. Cooney (Eds.) Making Sense of Mathematics Teacher Education. Dordrecht: Kluwer .

Jaworski, B. (2001b). 'How can research in mathematics education be useful for the practices of mathematics teaching?' In M. Blomhøj and T. Wedege, (Eds.) Matematikundervisningens praksis og matematikdidaktisk forskning - hvordan spiller de sammen? (Konferencerapport). Roskilde: Roskilde University, Center for Research in Mathematics Education.

Kemmis, S. (1985). Action Research and the Politics of Reflection. In D. Boud, R. Keogh, and D. Walker (Eds.) Reflection: Turning Experience into Learning. London: Kogan Page.

Kieran, C., Forman, E. and Sfard, A. (2001). Bridging the Individual and the Social: Discursive Approaches to Research in Mathematics Education. A PME Special Issue of Educational Studies in Mathematics, 46, 1-3.

Krainer, K. (1993). Understanding students' understanding: On the importance of cooperation between teachers and researchers. In P. Boero, (Ed.), Proceedings of the 3rd Bratislava International Symposium on Mathematical Teacher Education. Comenius Univ. Bratislava.

Krainer, K. (1998). Dimensions of Teachers’ Professional Practice: Action, Reflection, Autonomy and Networking. In T. Breiteig and G. Brekke (Eds) Theory into Practice in Mathematics Education. Proceedings from NORMA $\underline{98}$ pp 36-43 Kristiansand: Agder College Research Series.

Krainer, K. (2001). Teachers' Growth is more than the Growth of Individual Teachers. In F-L Lin and T. J. Cooney (Eds.) Making Sense of Mathematics Teacher Education. Dordrecht: Kluwer.

Lave, J. and Wenger, E. (1991). Situated Learning: Legitimate Peripheral Participation. Cambridge: Cambridge University Press.

Lerman, S. (1996). 'Intersubjectivity in Mathematics Learning: A Challenge to the Radical Constructivist Paradigm?' Journal for Research in Mathematics Education, 27(2), pp. 133-150.

Lerman, S. (2001). 'Cultural and Discursive Psychology: A Sociocultural Approach to Studying the Teaching and Learning of Mathematics.' Educational Studies in Mathematics 46, pp. 1-3.

Love, E. (1988). Evaluating Mathematical Activity. In D. Pimm (Ed.) Mathematics, Teachers and Children. London: Hodder and Stoughton. 
McIntyre, D. (1997). The Profession of Educational Research. In British Educational Research Journal, Vol 23 no. 2, pp. 127-140.

Mason, J. (2001). Researching your own Classroom Practice: From Noticing to Reflection. London: Routledge Falmer.

Mason, J., Burton, L. and Stacey, K. (1984). Thinking Mathematically. London: Addison Wesley.

Mathematical Association (1991) Develop your Teaching. Cheltenham: Stanley Thornes

Mohammad, R. F. (2002). From Theory to Practice: An understanding of the implementation of in-service mathematics teachers' learning from university into the classroom in Pakistan. Unpublished D. Phil Thesis. Oxford: University of Oxford.

Peterson, P. L. (1988). Teachers’ and Students’ Cognitional Knowledge for Classroom Teaching and Learning. Educational Researcher, June-July, pp 514.

Potari, D. \& Jaworski, B. (2002). Tackling Complexity in Mathematics Teaaching Development: Using the Teaching Triad as a Tool for Reflection and Analysis. Journal of Mathematics Teacher Education, Vol. 5, No. 4, pp 351380.

Rowland, T., Martyn, S., Barber, P. and Heal, C. (2000) 'Primary teacher trainees' mathematics subject knowledge and classroom performance.’ In T. Rowland and C. Morgan (Eds.), Research in Mathematics Education Volume 2: Papers of the British Society for Research into Learning Mathematics (pp. 3-18). London: British Society for Research into Learning Mathematics.

Schoenfeld, A. H. (1985). Mathematical Problem Solving. New York: Academic Press.

Schoenfeld, A. (1996). In Fostering Communities of Inquiry, Must It Matter That The Teacher Knows the Answer? For the Learning of Mathematics Vol 16, num 3, pp 11-16.

Schön, D.A. (1983). The reflective practitioner. London: Temple Smith.

Schön, D.A. (1987). Educating the reflective practitioner. Oxford: Jossey-Bass.

Sherin, M. G. (2002). A Balancing Act: Developing a Discourse Community in a Mathematics Classroom. Journal of Mathematics Teacher Education, 5, 3, 205-233.

Shulman, L. S. (1987). Knowledge and Teaching: Foundations of the New Reform. Harvard Educational Review Vol 57, No. 1 pp 1-23.

Skott, J. (2001). The Emerging Practices of a Novice Teacher: The Roles of His School Mathematics Images. Journal of Mathematics Teacher Education 4, 1, 3-28. 
Smyth, J. (1987). Transforming Teaching through Intellectualising the Work of Teachers. In J. Smyth (Ed.) Educating Teachers. London: Falmer Press.

Smyth, J.(1991). Teachers as Collaborative Learners. Buckingham: Open University Press.

Steffe, L. P. and Thompson, P. W. (2000). Interaction or Intersubjectivity? A Reply to Lerman. Journal for Research in Mathematics Education, Vol 31, No 2, 191-209.

Stenhouse, L. (1984). Evaluating curriculum evaluation. In C. Adelman (Ed.), The politics and ethics of evaluation. London: Croom Helm.

Thompson, A. (1992). Teachers' Beliefs and Conceptions: A synthesis of the research. In D. Grouws (Ed.) Handbook of Research on Mathematics Teaching and Learning. (pp. 127-146). New York: Macmillan.

Vulliamy, G. \& Webb, R. (1992). The influence of teacher research: Process or product? Educational Review, 44 (1) pp. 41-58

Wagner, J (1997). The unavoidable Intervention of Educational Research: A Framework for Reconsidering Research-Practitioner Cooperation. Educational Researcher, Vol. 26 number 7. 13-22.

Wells, G. (1999). Dialogic Inquiry: Toward a Sociocultural Practice and Theory of Education. Cambridge: Cambridge University Press.

Wenger, E. (1998). Communities of Practice: Learning, Meaning and Identity. Cambridge: Cambridge University Press.

Wiliam, D., Lee, C., Harrison, C. \& Black, P. (2003 - in press). Teachers developing assessment for learning: impact on student achievement. Assessment in Education, Policy and Practice.

Wilson, S., Shulman, L. and Richert, A. (1987). 150 Ways of Knowing: Representations of Knowledge in Teaching. In J. Calderhead (Ed.)

Exploring Teachers’ Thinking. London: Cassell pp104-124. 